\title{
An Analysis of the Differences in Educational Ideas between Chinese and American Senior High School
}

\author{
Xiaoshun Zhang \\ High School Attached to Northeast Normal University \\ Changchun, China 130021
}

\begin{abstract}
Based on the learning experience and educational thought theory in the United States, the author puts forward six differences in educational ideas between Chinese and American senior high schools, namely, test ability and qualified citizens, scientism and multiple intelligences, seeking common ground and seeking difference, high order thinking and broad knowledge, strictness and freedom and equality, and competitive consciousness and cooperation and sharing.
\end{abstract}

Keywords-educational ideas; Chinese and American high school; difference; qualified citizen

\section{INTRODUCTION}

The author has been to Free Valley High School in Chicago to study for half a year. During this half year, he attends classes, exchanges, records, interviews, discusses, and takes part in various activities of teachers and students, and deeply feels the American culture, and the differences in teaching and educational ideas between Chinese and the United States senior high school. Because of the different history, culture and educational system, there are great differences between American and Chinese senior high schools in educational ideas, systems, teaching methods, and curriculum and so on. To sum up, there are six main aspects as follows.

\section{TEST ABILITY AND QUALIFIED CITIZENS}

The educational policy system can't exist independently from the historical and social system. Generally speaking, the utilitarianism of modern education in China is too strong, which has a great relationship with the imperial examination system in ancient China. The learning motivation of the imperial examination system is that "a good scholar will make an official", "those who are engaged in intellectual work manage others while those who are engaged in physical work are managed by others", "there are golden houses in the book; there are thousands of grain in the book, and there are pretty women in books". The study way is "being not care what is going on in outside world, only reading the holy and virtuous book"; and the spirit of "studying at a cold window" is encouraged. From ancient times to the present, Chinese people regard learning as a "stepping stone" to a happy life. The current Chinese education system and the selection standard of college entrance examination decide that the grade is the main standard to judge the students. The employment system of the society is also "emphasizing academic credentials rather than ability". Usually the kind of university one is admitted to determines the people's career, income, social status and future development space to a large extent [1]. Due to the scarcity of high-quality college education resources, Chinese people are willing to compare the college entrance examination as "thousands of troops and horses across the single-log bridge." In this context, test ability in college entrance examination has become an overwhelming event. In addition to the subjects in college entrance examination, only a few physical education and music classes and students have very little spare time for cultural life. Their parents do not need them to undertake any housework. The school teaching mainly adopts the Prussian education model, and the teaching method is more like the training of some technical disciplines. That is, through a large number of repeated practice to achieve the purpose of memory and proficiency. Schools are often compared to "ivory towers," which also shows that secondary education is seriously divorced from university and society. In fact, most of the students in their teenage years are mainly "ascetic monks" who had no interest in learning.

The core idea of American education is to cultivate qualified citizens, which is mainly influenced by American educator John Dewey and British educator John Henry Newman. John Dewey, an American pragmatist educational thinker, advocates such views as "education is life", "school is society" and "the goal of education is to cultivate qualified citizens", which greatly influenced the current educational system and mode of education in the United States. He also proposes two essential elements of a qualified citizen: spirit of individuality and spirit of cooperation. In his book "The Ideal of the University", Newman makes a famous exposition of the educational goal of the university. "The university education is to teach people how to adapt to others, how to put oneself in the other's shoes, how to convey their ideas to others, how to influence others, and how to understand each other, and tolerate each other, so that he can get along with any group of people naturally; he has something in common with anyone. He knows when to speak and when to be silent ... "[3], Newman describes the basic qualities that a qualified citizen must possess. The common feature of the two educators is that they insist that the main duty of the school is to cultivate the students' humanistic spirit, rather than the accumulation of knowledge. In the United States, the humanistic spirit is essentially a 
kind of free, conscious and critical spirit, the ability to judge good and evil, beauty and ugliness, right and wrong, and tolerance, respect and cooperative spirit, and even the harmony between man and nature [4].

In the process of education, China and the United States have different emphasis on practical subjects and human literature, which reflects the different understanding of educational field in educational purposes: whether education is to cultivate a full-developed person, or to cultivate people into a labor machine. The science education and the humanities education are not completely irreconcilable two poles in opposite sides, while the two complement each other, and the seed of modern science is precisely bred in the core of western humanism spirit [5]. Therefore, in the process of education, the two cannot be neglected, since science education is intended to help students to seek truth, and humanities education is aimed at guiding people to pursue light. Only with the guidance and escort of humanistic spirit, the development of science can show its vigorous vitality and truly reflect the core value of bringing benefit to society and mankind.

\section{SCIENTISM AND MULTIPLE INTELLIGENCES}

In modern times, China almost completely accepted Newton's mechanical classical theory and Darwin's biological theory of evolution in the field of science, and introduced Marxist materialism almost indiscriminately in the humanities, while in the field of production; it was deeply influenced by the large-scale industrial production in the West. The strategic goal of the Party and the state is to realize the four modernizations of "industry, agriculture, national defense, and science and technology." In order to catch up with Britain and the United States as soon as possible, China attaches great importance to physics, chemistry, biology and other scientific disciplines, the belief in science and the pursuit desire of material in the whole society have reached an unparalleled height, and then "scientism" above all kinds of religions is generated. In this model, Chinese higher education is popularized rapidly, and economy also develops rapidly thereupon, but with the increase of social contradictions, the well-being of the people is getting lower and lower.

It corresponds to the theory of multiple intelligences in the United States. 1983, Professor Howard Gardner, a cognitive psychologist at Harvard University, proposed the theory of multiple intelligences for the first time in his book The Structure of Intelligence. Later, after years of research, he and his team gradually improved the theory, dividing human intelligence into nine different types: musical intelligence, visual-spatial intelligence, linguistic intelligence, logical-mathematical intelligence, body-motor intelligence, interpersonal intelligence, introspective intelligence, natural intelligence, spiritual intelligence and existential intelligence [7]. Gardner's "multiple intelligences" theory breaks through the hypothesis of traditional intelligence theory, and at least provides a powerful theoretical support for the curriculum and student evaluation of American high school.
In the curriculum, the rich curriculum resources and course selection system, mobile learning system and other forms basically meet the needs of students' employment, education and hobbies. For example, Free Valley High School in D128, Illinois, offers curriculum in nine major areas including vocational and technical education in (also divided into applied technology, business education, and family and consumption), English, visual and performing arts (also divided into art, music, and stage drama), international language, mathematics, physical and health, driving, science, and social sciences. Adding special education, there are nearly 150 required and elective courses.

In the aspect of student evaluation, the theory of multiple intelligences has corrected the narrow emphasis on language and mathematical logic in the past, emphasizing the purpose of evaluation should not classify, screen and eliminate the students, but discover the different potential of the students and guide them. Evaluation should not take the single academic achievement as the only standard, but should evaluate the intelligence of students in different aspects from multiple angles with a comprehensive and developmental vision [8].

\section{SEEKING COMMON GROUND AND SEEKING DIFFERENCE}

The problem of seeking common ground and difference can also be understood as the problem of receiving and inheriting or questioning and innovating. The most obvious example is a story that everyone is familiar with. When children finish painting, Chinese children usually ask "look like or not" while American children ask "good or bad," and the idea of seeking common ground and difference begins to manifest itself in young children.

In China's educational ideas, the most important thing is to cultivate a strict and rigorous academic spirit. The Chinese people respect knowledge, worship reading, and always have a kind of holy attitude of all-round acceptance and inheritance of the well-known scholars and the knowledge system they represent [9]. The examination system in China is the standardized examination that seeks the only and accurate answer. Classroom teaching in China is a typical teacher-centered teaching model. Teachers usually teach knowledge and supervise students in an authoritative and serious manner in front of the platform. "Speaking, practicing and testing" is a magic weapon that ensures students to get high marks. This teaching mode is characterized by large capacity of knowledge, rigorous structure, serious attitude and high learning efficiency, but it also makes students rely too much on teachers and textbooks, and cannot ask breakthrough and creative questions [10].

In contrast, the United States pays more attention to the cultivation of innovative spirit, their educational philosophy is to cultivate students who dare to question experts and scholars, and dare to challenge authority. Their study of knowledge is a kind of expanding and creative learning, instead of passive acceptance [11]. The brand founder of Apple, Steve Jobs was once asked by a student at Stanford University when giving speech: "How can I be like you?" 
How can I become the people like you?" Jobs gave a famous answer: "Alternative thinking!"

Another education view commonly agreed in American educational circles is to respect differences. It is the difference of human beings that forms the basis of the colorful creativity of the whole human race. Education is different from manufacturing industry which needs standardization, since only standardization can large industrial production is made possible, while education precisely needs individuation, and diverse personality potential is a huge force to promote social progress. It is the essence of American education to let every child gradually find his or her potential, build self-confidence, make his or her own creative contribution to society in different fields, and realize his or her self-worth. Ms. Zhang Jie, the principal of Stevens Middle School in New York, said that the people's basic quality can't be measured by grade. To help students light up their dreams as much as possible to bravely move towards the road in future is the real people oriented [12]. In the process of teaching, teachers encourage students to express their views and methods at any time. The teacher guides the student to carry on the independent individual thought activity, and should be forbidden to provide "the only correct answer" to the questions in the aspects of politics, religion, history, geography and literature. They should encourage the existence of many different opinions, and avoid replacing the student to think. In the examination, the emphasis of the assessment is not showing the level of analysis ability, but examining the rationality of analysis of the answer [13].

In a word, Chinese education emphasizes the cultivation of students' convergent thinking, and rigorous and precise spirit, while American education emphasizes the cultivation of students' critical thinking and divergent thinking, and the cultivation of students' self-confidence, self-determination and self-reliance [14].

\section{HIGH ORDER THINKING AND BROAD KNOWLEDGE}

As a whole, the knowledge of various subjects in Chinese high school develops in depth, which means that the scope of knowledge taught is not wide, but the connotation and extension of the knowledge involved are excavated deeply. The requirements on some high order thinking abilities of students' "inferential capability", "ability of analysis and synthesis", and "ability to deal with physical problems by applying mathematics" are very high.

However, the American education pursues the width of knowledge, which is mainly manifested in three aspects: first, as mentioned above, opens a large number of subjects; secondly, from the teaching material to the teacher, the content of each subject tries to link the knowledge point with the reality of production and life; third, emphasis is put on "learning from doing". Especially in science, a large number of demonstration experiments and group experiments will be made in class.

\section{STRICTNESS AND FREEDOM AND EQUALITY}

Discipline, criticism and punishment are still effective means for Chinese parents and schools to manage the students. In 2011, China Guangming Daily published an article entitled "The Battle Song of Tiger Mother", which referred to the three "successful experiences" of the Yale professor "Tiger Mother" Cai Mei-er teaching daughters: first, she ignores the self-respect of her children; second, the children are determined to be filial to their parents; third, she believes that children do not know right and wrong, so they need the guidance of parents. The tip status of "Tiger Mother" and the outstanding performance of the two daughters under the "fierce mother" upbringing pose a challenge for the concepts of American parents respecting children and encouraging children's "democratic" and "benevolent".[15]. Many teachers in China still believe in the idea of "a strict teacher produces outstanding students." Strict management is still very effective for students to master knowledge and test skills, but it is not conducive to students' interest in learning and self-confidence training, and blaming and criticizing will only increase students' inferiority complex. As Amy Tan, a Chinese-American writer, points out in the novel "Joy luck club", "When you just criticize, it seems to mean that you just want to fail." [16]

American schools attach great importance to the cultivation of students' self-esteem and self-confidence. There is hardly any criticism in the classroom. Even if some students are naughty or can't answer the questions raised by teachers, they are encouraged by teachers. The classroom atmosphere is free and relaxed and students express their views, discuss and even debate at any time in the classroom. They believe that self-confidence and creativity are sometimes more important than knowledge. Of course, in this mode, many students in the United States who have poor self-perception and self-control tend to be mediocre and confused. They believe that they have the "right" to choose and play, but they are not mature enough to be responsible for their own future, so there will be many students who do not obey discipline, do not work hard enough, and even indulge in drinking and taking drugs. Excessive attention to children's self-esteem is making the United States a "country in need of help." [17]

China and the United States are obviously two extremes in student management. Most Chinese educators believe that education without punishment is incomplete, but severity and punishment should not be the hangman of students' selfconfidence and creativity.

\section{COMPETITIVE CONSCIOUSNESS AND COOPERATION AND SHARING}

Influenced by the traditional imperial examination system, the idea of "survival of the fittest in natural selection" in Darwin's theory of evolution, the relative scarcity of per capita resources and the wave of economic reform, China attaches great importance to the cultivation of students' "competitive consciousness" in both family education and school education--they like to compare themselves with others in everything. Students are compared 
with others in their study, teachers are compared with other teachers in their subject teaching, and class teachers are compared with other classes in charge of the class, so students are encouraged to have competitive consciousness in their ideological education. Thinking carefully, "comparison" has played a positive role in cultivating students' learning motivation and persistent learning perseverance, but it also leads the Chinese to be conservative and less capable to cooperate with others. Bo Yang said in his "Ugly Chinese": "One Chinese is a dragon, while three Chinese are worms." This also shows that the Chinese people have a poor sense of cooperation, and are prone to be lazy and skidding, intrigue against each other and care too much about their own interests in collectives.

In today's society, all walks of life attach great importance to the cooperation consciousness and team spirit. Bernard Shaw said: "If you have an apple, and I have an apple, when we exchange them, each one of us only has one apple." If you have an idea, and I have an idea, when we exchange the ideas, each one of us has two ideas", which also shows the importance of cooperation in the field of ideology. High school education in the United States is permeated with this education concept of cooperation and sharing. In the world literature class, each student actively offers suggestions around a theme; in the group experiment in science class, such as physical, chemical and biological, and so on, the team members work together to complete a project; teachers of the same subject share their own creative experiments when preparing lessons in groups ...

\section{CONCLUSION}

China and the United States are two superpowers in the world today. Both of them attach great importance to basic education, but there are huge differences in the education concept of high school. Generally speaking, "Chinese education lacks the cultivation of the students' ability, so students are short of the ability to think, explore and innovate, as well as the questioning spirit, the spirit of adventure and the spirit of criticism, which is not conducive to the cultivation of students' self-confidence" [18]. There are still many places for Chinese educators to learn from in American educational ideas and system.

\section{REFERENCES}

[1] Liu Aici: An analysis of the difference between Chinese and Western education [J]. Journal of Women's Academy at Shandong, 2007.

[2] Zhang Guoji: Exploration and Analysis of American Educational Ideas--Notes of Investigation in America [J]. Journal of Educational Science of Hunan Normal University, 2005 (5): 57-62.

[3] John Henry Newman. The Ideal of a University [M]. Hangzhou: Zhejiang Education Publishing House, 2001.

[4] Sally: A survey of the characteristics of educational ideas in famous American schools [J]. Journal of Shenyang College of Education, 2008 (4): 29-32.

[5] Gardner H. Frames of Mind: The theory of multiple intelligences [M]. New York: Basic Books, 1983.

[6] Gardner H. Are there additional intelligences: The case for naturalist,spiritual, and existential intelligence $[\mathrm{M}] / / \mathrm{In} \quad \mathrm{J}$
Kane(Ed.).Education,information, and transformation.Upper Saddle River,NJ: Merrill-prentice Hall,1998:111-131.

[7] Yi Xingxia: Establishing the multiple evaluation system based on the theory of multiple intelligences [J]. Journal of Changchun University of Science and Technology, 2011 (8): 145-146.

[8] Zhang Yan and Huang Yin. On the Differences and Conflicts between Chinese and American Educational Ideas--A Case Study of Amy Tan's Novels [J]. Writer, 2010 (08).

[9] Li Sijing: Comparative Analysis of Educational Ideas between China and the United States [J]. Journal of Wuhan Institute of Shipbuilding Technology, 2009 (4): 4-6

[10] Xiao Yuanqi. Secrets of American Education [N]. China Education Daily, 2014-10-29.

[11] Yu Xiaokui. The Battle Song of the Tiger Mother: Shaking American Educational Ideas [N]. Guangming Daily, 2011-02-15.

[12] Amy Tan. Joy luck club [M]. Shanghai: Shanghai Translation Publishing House, 2015.

[13] Zhao Yuzhang: Comparative study of educational concepts between China and the United States [J]. Intelligence, 2015 (03): 34-35. 